Journal of Community Based Environmental Engineering and Management, 2020, Vol. 4, No. 2: 63-74

\title{
DISCRIMINANT ANALYSIS TOWARD DEMOGRAPHIC CHARACTERISTICS OF CIKAOBANDUNG VILLAGE COMMUNITY IN CITARUM HARUM PROGRAM
}

\author{
Diki Azis, Aulia Fashanah Hadining*, Kusnadi Kusnadi \\ Industrial Engineering Department, University of Singaperbangsa Karawang
}

\begin{abstract}
The Indonesian Government through the Citarum Harum program formulates steps to control damage and pollution with various indicators of success, including placing the community around the river to behave in an environmentally friendly manner. The results of research on people's behavior intentions in the Citarum Harum program are influenced by various factors, but the demographic characteristics have not been studied whether each category of gender, age, latest education, and monthly income has clear differences in answering the questionnaire statement indicators and which indicators are make a difference. This research was conducted in RW 02, Cikaobandung Village with a discriminant analysis method. The results showed that there were no clear differences in the gender groups and there were clear differences between the group's latest educational characteristics, monthly income and age. Indicators that differ in age groups are IM2, last education is SN1, and monthly income is IM2, PN2 and BI1.
\end{abstract}

Keywords: citarum harum, community participation, discriminant analysis

\section{Introduction}

The heavy polluted status of the Citarum River is very worrying (Badan Pusat Statistik, 2018) and not suitable for use as raw water (Prinajati, 2019). If this is not handled, it will have a bad impact on the community, especially those on the riverbanks.

The Citarum Harum Program is one of the efforts to decrease Citarum River pollution through Perpres No. 15 of 2018 (Hadining et al., 2020). One of the efforts to implement the Citarum Harum program can be realized through several series of studies where the results function as information and data updating to support the implementation of the Citarum

\footnotetext{
${ }^{*}$ Corresponding Author:

E-mail: aulia.fasha@staff.unsika.ac.id
}

Received: 25 August 2020

Revised : 3 September 2020

Accepted: 7 September 2020
Harum program in accordance with article 13 point d of Perpres No. 15 of 2018.

The series of research that correlates with each other regarding the Citarum Harum program starts from research on the water quality of the Jatiluhur Reservoir by Sari et al (2020), where in that study the water quality is measured by considering the physical-chemical aspects with the conclusion that the water quality has decreased.

The decline in quality is due to fish farming activities that exceed the capacity of the Jatiluhur Reservoir and polluted water has the potential to endanger the health of the community in the Jatiluhur Reservoir outlet area (Sari et al., 2020).

The fact that the quality of water is polluted and dangerous makes the Jatiluhur outlet community need to adopt a behavior pattern that cares for the environment, this is done because the behavior of people who care for the environment 
is one of the keys to success in handling pollution (Badan Pusat Statistik, 2018).

The first step to change the pro-enviroment behavior is the public or community awareness (Kamaruddin et al., 2016). The community awareness about the environment is also an indicator of the implementation of the Citarum Harum Program (Kamil, 2019), where the behavioral Intention can be influenced by several factors (Ajzen, 2011) and proenviromental behavior can be formed with the supportive social environment (Laurens, 2012).

Previous research on the intention to behave in the community in participating in the Citarum Harum program was researched by Hadining et al. (2020), in which that study aims to examine what factors influence the behavioral intention of the community in the Citarum Harum program.

Research conducted by Hadining et al. (2020) has a correlation place with water quality research conducted by Sari et al. (2020) where the research object by Hadining et al. (2020) alive in the Jatiluhur Reservoir outlet area, in Cikaobandung Village.

Hadining et al. (2020) research derived from the processing of public perception data on answers to the questionnaire indicator statement. The results show that the Incentive Measures (IM), Personal Norms (PN) and Preceived Behavioral Control (PBC) factors are significant factors affecting Behavioral Intention.

Environmental Theory Knowledge (ETK) and Environmental Practical Knowledge (EPK) factors also directly influence Attitude Toward The Behavior (ATT) (Hadining et al., 2020). The series of research carried out Hadining dkk. (2020) needs to be strengthened in terms of a study of demographic characteristics.

This is because there is an unbalanced percentage of one category with other demographic characteristics (gender, age, latest education and monthly income) in the research object community results at Hadining et al. (2020), for example in the demographic characteristics of the latest education where each category has a different percentage (Table 1).

Research on these demographic characteristics needs to be carried out as a continuation of a series of studies on the Citarum Harum program regarding water quality and community behavior with the aim of knowing whether demographic characteristics (gender, age, latest education and monthly income) have clear differences, and which indicators are make a difference using discriminant analysis.

This research is also expected to have a contribution value to the Citarum Harum program as a description of information and data for Citarum Harum program implementers to mapping demographic characteristics (gender, age, latest education and monthly income) in the implementation of the Citarum Harum program.

On the other hand, several previous studies have an environmental theme, such as that done by Esteban et al. (2020) with the discriminant analysis method, it was found that gender and education level as the dependent variable had differences in each group category when tested with indicators regarding environmental education.

Discriminant analysis discusses and aims to form a new group of individuals into existing groups based on the score of the independent variable (Supartini et al., 2017).

Discriminant analysis will form a function of the independent variable that will discriminate (predictor) the dependent variable to determine which respondents will enter the specified category (Rahman \& Sari, 2018).

Discriminant analysis has similarities with logistic regression where both can answer research on classification. The difference between that method is in from the assumptions 
used where the logistic regression has a few assumptions that must be fulfilled while the discriminant analysis is the opposite, but the discriminant analysis is more accurate than logistic regression (Bashiru \& Adekunle, 2015).

Another reason for the use of this method is that discriminant analysis is widely used in various fields of study, including in the field of education (Marino et al., 2014), measuring employee performance (Azis \& Basuki, 2014), measuring customer satisfaction (Rahman \& Sari, 2018) and customer satisfaction (Santos \& Gonçalves, 2019).

\section{Research Methodology}

\section{Data and Research Location}

Secondary data from research results conducted by Hadining et al. (2020) in RW 02, Cikaobandung Village, Jatiluhur, Purwakarta, with a total population of 285 people and 170 people as samples (using Slovin formula with $5 \%$ error rate) are use in this research.

\section{Research Variable}

The dependent variable in this study is the demographic characteristics (Gender, Age, Last Education and Monthly Income) as shown in Table 1.

Table 1. Demographic characteristics as dependent variable, JK: Gender, US: Age (Years), PT: Latest Education, PBl (Rupiah): Monthly Income

\begin{tabular}{|c|c|c|c|}
\hline Variable & Category & Qty. & $\%$ \\
\hline \multirow{2}{*}{ JK } & 1. Male & 92 & 54.1 \\
\hline & 2. Female & 78 & 45.9 \\
\hline \multirow{5}{*}{ US } & 1. $<14$ & 2 & 1.2 \\
\hline & 2. $15-24$ & 24 & 14.1 \\
\hline & 3. $25-44$ & 61 & 35.9 \\
\hline & 4. $45-65$ & 76 & 44.7 \\
\hline & 5. $>65$ & 7 & 4.1 \\
\hline
\end{tabular}

Source: Hadining et al. (2020)
Table 1. Demographic characteristics as dependent variable, JK: Gender, US: Age (Years), PT: Latest Education, PBl (Rupiah): Monthly Income (Advanced)

\begin{tabular}{|c|c|c|c|}
\hline Variable & Category & Qty. & $\%$ \\
\hline \multirow{6}{*}{ PT } & $\begin{array}{l}\text { 1. Not going to } \\
\text { school }\end{array}$ & 1 & 0.6 \\
\hline & 2. Elementary & 63 & 37.1 \\
\hline & $\begin{array}{l}\text { 3. Junior High } \\
\text { School }\end{array}$ & 51 & 30 \\
\hline & $\begin{array}{l}\text { 4. Senior High } \\
\text { School }\end{array}$ & 55 & 32.4 \\
\hline & $\begin{array}{l}\text { 5. Studying in } \\
\text { College }\end{array}$ & 0 & 0 \\
\hline & 6. Bachelor Degree & 0 & 0 \\
\hline \multirow{5}{*}{ PBl } & 1. $<500,000$ & 67 & 39.4 \\
\hline & $\begin{array}{l}\text { 2. } 500,000- \\
2,000,000\end{array}$ & 55 & 32.4 \\
\hline & $\begin{array}{l}\text { 3. } 2,000,000- \\
3,500,000\end{array}$ & 10 & 5.9 \\
\hline & 4. $\begin{array}{l}3,500,000- \\
5,000,000\end{array}$ & 33 & 19.4 \\
\hline & 5. $>5,000,000$ & 5 & 2.9 \\
\hline
\end{tabular}

Source: Hadining et al. (2020)

Table 1 shows that gender will be the dependent variable by grouping into 2 categories, age into 5 grouping categories, latest education into 6 grouping categories and monthly income into 5 group categories.

The independent variables in this study are 30 statements in the research indicators Hadining et al. (2020) as measured by a Likert scale of $1=$ strongly disagree up to $5=$ strongly agree, the independent variable in this study has met the assumption of a normal multivariate distribution (Hadining et al., 2020). The research questionnaire statement indicator data is attached to Appendix A.

\section{Linear Discriminant Analysis}

Liniear discriminant analysis is a pattern identification technique and is usually used after the application of MANOVA to compute linear 
combinations of several subject groups to differentiate (Louppis et al., 2019), by determining the classification measure based on the original method and cross validation (Chudzinska \& Baralkiewicz, 2011).

\section{Stepwise Discriminant Analysis}

Stepwise discriminant analysis is very useful to predict variables, because with the many predictor variables involved in the analysis, this method automatically selects the best variable to be included in the discriminant function (Louppis et al., 2019). Stepwise discriminant analysis is widely used in selecting models with three or more groups (Baxter, 1994). In this study, the discriminant analysis used was stepwise discriminant analysis with more than 2 groups (multiple).

\section{Malhanobis Distance}

Malhanobis distance is a statistical technique that can be used to calculate how far a point is from the normal multivariate (Etherington, 2019). Malhanobis Distance is also used to detect outliers (Li et al., 2019) and widely used in multivariate analysis such as discriminant analysis, classification and clustering (Ghorbani, 2019).

\section{Discriminant Analysis Assumptions}

The basic assumption that must be met in the discriminant analysis is that the data must have a multivariate normal distribution and the covariance matrices are the same (Rahman \& Sari, 2018). The dependent and independent variables in this study have fulfilled the multivariate normal distribution (Hadining et al., 2020). This research use the SPSS version 25 software to help processing data.

\section{Results and Discussion}

\section{Test of Equality Group Means}

The first test conducted is the test of quality group means, where the results of this test provide the Wilk's Lambda and Univariate $F$ ratio values for each independent variable. By looking at the significance value of each independent variable, it can be concluded whether the dependent variable can be distinguished by the independent variable or not (Ghozali, 2016). The results of the group means test of equality are shown in Table 2.

Table 2 Test of Equality Group Means

\begin{tabular}{|c|c|c|c|c|}
\hline \multirow[t]{2}{*}{$\begin{array}{l}\text { Independent } \\
\text { Variable }\end{array}$} & \multicolumn{4}{|c|}{$\begin{array}{c}\text { Significance value } \\
\text { independent var. toward } \\
\text { the dependent } \\
\text { var.characteristics }\end{array}$} \\
\hline & JK & US & PT & PBI \\
\hline ETK1 & 0.871 & 0.348 & 0.373 & 0.893 \\
\hline ETK2 & 0.989 & 0.175 & 0.228 & 0.827 \\
\hline ETK3 & 0.292 & 0.477 & 0.091 & 0.640 \\
\hline EPK1 & 0.110 & 0.762 & 0.175 & 0.637 \\
\hline EPK2 & 0.128 & 0.968 & 0.549 & 0.388 \\
\hline EPK3 & 0.714 & 0.560 & 0.268 & 0.896 \\
\hline $\mathrm{GC} 1$ & 0.742 & 0.654 & 0.335 & 0.676 \\
\hline GC2 & 0.689 & 0.133 & 0.381 & 0.856 \\
\hline GC3 & 0.748 & 0.218 & 0.942 & 0.545 \\
\hline SN1 & 0.411 & 0.597 & 0.018 & 0.822 \\
\hline SN2 & 0.909 & 0.842 & 0.553 & 0.415 \\
\hline SN3 & 0.793 & 0.829 & 0.034 & 0.337 \\
\hline PBC1 & 0.910 & 0.138 & 0.525 & 0.385 \\
\hline PBC2 & 0.958 & 0.227 & 0.599 & 0.832 \\
\hline PBC3 & 0.849 & 0.755 & 0.885 & 0.533 \\
\hline
\end{tabular}


Tabel 2 Test of Equality Group Means

(Advanced)

\begin{tabular}{|c|c|c|c|c|}
\hline \multirow{2}{*}{$\begin{array}{l}\text { Independent } \\
\text { Variable }\end{array}$} & \multicolumn{4}{|c|}{$\begin{array}{l}\text { Significance value } \\
\text { independent var. toward the } \\
\text { dependent var.characteristics }\end{array}$} \\
\hline & JK & US & PT & PBI \\
\hline IM1 & 0.523 & 0.153 & 0.263 & 0.412 \\
\hline IM2 & 0.427 & 0.011 & 0.934 & 0.019 \\
\hline IM3 & 0.376 & 0.115 & 0.293 & 0.081 \\
\hline PN1 & 0.943 & 0.095 & 0.851 & 0.165 \\
\hline PN2 & 0.719 & 0.695 & 0.531 & 0.014 \\
\hline PN3 & 0.475 & 0.318 & 0.240 & 0.235 \\
\hline BI1 & 0.404 & 0.304 & 0.189 & 0.143 \\
\hline BI2 & 0.246 & 0.385 & 0.484 & 0.346 \\
\hline BI3 & 0.091 & 0.578 & 0.226 & 0.676 \\
\hline ATT1 & 0.499 & 0.710 & 0.454 & 0.030 \\
\hline ATT2 & 0.930 & 0.436 & 0.742 & 0.674 \\
\hline ATT3 & 0.706 & 0.377 & 0.889 & 0.117 \\
\hline PB1 & 0.467 & 0.897 & 0.650 & 0.382 \\
\hline PB2 & 0.614 & 0.333 & 0.441 & 0.966 \\
\hline PB3 & 0.820 & 0.095 & 0.733 & 0.905 \\
\hline
\end{tabular}

The significance value of the independent variable are $<0.05$, it means that the independent variable is able to provide a difference and vice versa. Table 2 shows that the independent variable does not make a difference to the gender dependent variable (JK), so that further discriminant analysis testing cannot be carried out.

The independent variable IM2 is able to make a difference to the dependent variable age (US), the independent variable SN1 and SN3 is able to make a difference to the dependent variable last education (PT) and the independent variables PN2 and ATT1 are able to provide differences in the dependent variable monthly income, but independent variables This does not guarantee to be included in the discriminant function, so it is necessary to carry out further analysis.

\section{Assumption of Covariance Matrix Equality}

The assumption of covariance matrix equality is carried out using the Box's M test by looking at the significance value with the acceptance of a test significance value is $>0.05$ which means that the covariance matrix is homogeneous and fulfills the assumption of covariance matrix equality and the test significance value $<0.05$ means that the covariance matrix is not similar (Ghozali, 2016). The results of the box's M test are shown in Table 3.

Table 3 Significance value of box's M test

\begin{tabular}{cc}
\hline Variable & $\begin{array}{c}\text { Significance value of } \\
\text { box's M test }\end{array}$ \\
\hline Age (US) & 0.570 \\
\hline $\begin{array}{c}\text { Latest Education } \\
(\mathrm{PT})\end{array}$ & 0.101 \\
\hline $\begin{array}{c}\text { Monthly Income } \\
(\mathrm{PBl})\end{array}$ & 0.670 \\
\hline
\end{tabular}

\section{Discriminant Function}

The significance value of all variables are more than 0.05, that means the assumption of covariance matrix equality is fulfilled and can be followed by the formation of the discriminant function. The discriminant functions formed in this study are shown in Table 4. 
Table 4 Discriminant function

\begin{tabular}{cl}
\hline $\begin{array}{c}\text { Dependent } \\
\text { Variable }\end{array}$ & Discriminant Function \\
\hline US & US $=-3.479+(0.989 * \mathrm{IM} 2)$ \\
\hline $\mathrm{PT}$ & $\mathrm{PT}=-3.531+(0,915 * \mathrm{SN} 1)$ \\
& \\
\hline & $1 . \mathrm{PBl}=(-$ \\
& $0.183)+(0.830 * \mathrm{IM} 2)+(0.079$ \\
& $* \mathrm{PN} 2)+(-0.797 * \mathrm{BI} 1)$ \\
\cline { 2 - 3 } $\mathrm{PB1}$ & PBl $=(-3.856)+(-$ \\
& $0.261 * \mathrm{IM} 2)+(1.086 * \mathrm{PN} 2)$ \\
& $+(0.183 * \mathrm{BI} 1)$ \\
\cline { 2 - 3 } 3. & $\mathrm{~PB} 1=(-$ \\
& $4.819)+(0.558 * \mathrm{IM} 2)+(-$ \\
& $0.068 * \mathrm{PN} 2)+(0.818 * \mathrm{BI} 1)$ \\
\hline
\end{tabular}

The discriminant function in Table 4 is formed using the stepwise method by including the expensive nobis distance procedure (significant value 0.05 ) to determine the largest variable that discriminates against the dependent variable. The value of the variation in the dependent variable that can be explained by the variable is taken from the percent value of the canonical correlation which is squared and the accuracy of the discriminant function in grouping the data is obtained from the cross-validation value.

The independent variable IM2 is the largest variable that discriminates against the age variable, with the variation value of the dependent variable that can be explained by the IM2 independent variable of $7.5 \%$ with $44.1 \%$ of the 170 processed data entered in accordance with the original data. While the value of sig. Chi-square 0.011 which is significant. The accuracy of the discriminant function (crossvalidation) of the age variable was $44.1 \%$.

The variable that is able to discriminate the dependent variabel lastest education variable is the independent variable SN1, with the variation value of the dependent variable that can be explained by the SN1 independent variable of $5.8 \%$ with $25.9 \%$ of the 170 processed data entered in accordance with the original data. The accuracy of the last educational variable discriminant function is $25.3 \%$.

The number of discriminant functions formed in the dependent variable of monthly income is 3 functions, the independent variable IM2, PN2, BI1 becomes the variable that differentiates the monthly income variable. In explaining the dependent variation, the first discriminant function gives a percentage of $12.4 \%$, the second discriminant function gives a percentage of $6.8 \%$, and the third discriminant function gives a percentage of $0.1 \%$. $35.5 \%$ of the 170 data processed according to the original data. The accuracy of the formed discriminant function is $27.6 \%$.

\section{Function At Group Centroids}

Function at group centroids used to determine the grouping cut-offs (Ghozali, 2016), in this research the function at group centroids of demographic characteristics of age and education is shown in Figure 1 and monthly income is shown in Figure 2 below.
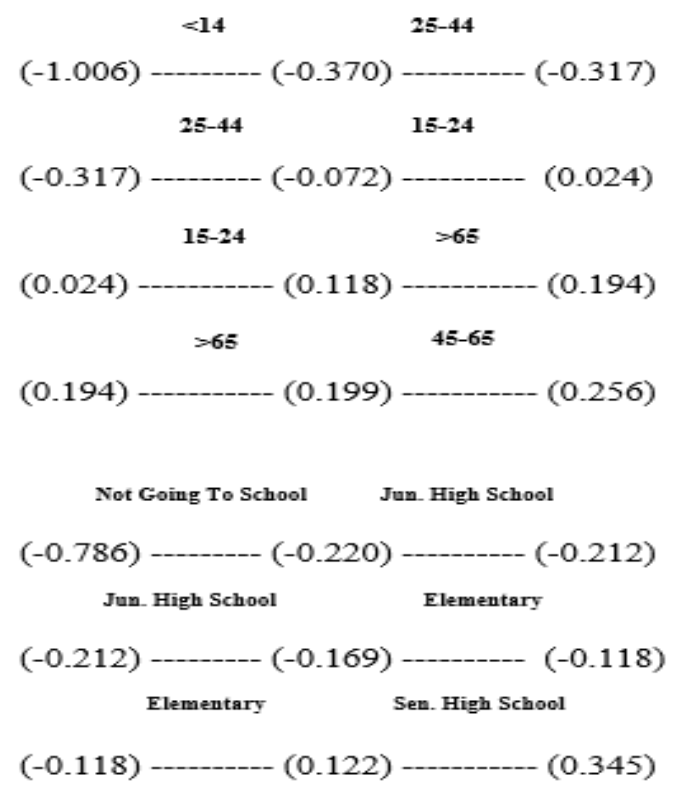

Figure 1. Function at group centroids age and latest education 
Figure 1 shows the cut-off value of each category, for example the cut-off value between the demographic characteristic categories aged less than 14 years and $25-44$ years is -0.37036 which means that if the $\mathrm{Z}$ score is $-1.006<\mathrm{Z}$ Score $<-0,37036$ will be grouped into the age category under 14 years.

If the $\mathrm{Z}$ score is $-0.37036<\mathrm{Z}$ Score $<-0.317$ then it will be grouped into the age category under 14 years. This applies to all cut-off values of each relationship between categories of demographic characteristics, including the characteristics of monthly income in Figure 2.

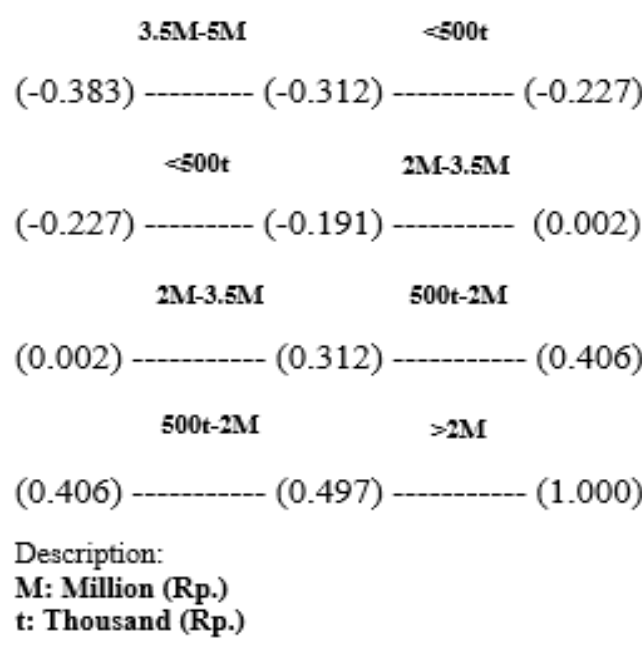

Figure 2. Function at group centroids monthly incomes

Specifically for the characteristics of monthly income, the 1st discriminant function is taken because it has a higher canoncial correlation value than the 2 and 3 discriminant functions

\section{Managerial Implications}

The demographic characteristics of the respondents were classified as a result of the study Hadining et al. (2020) conducted to see which demographic characteristics provide differences in answering the questionnaire indicators regarding community behavior research in the Citarum Harum program.
Gender demographic characteristics do not show any differences, meaning that the answers to the questionnaire indicators from all independent variables cannot be predicted and cannot be grouped into the male or female group. This requires further research if it is related to the Citarum Harum program.

The independent variable SN1 (people whom I consider important, argues that I should not throw garbage into the river) which differentiates the group of the latest educational demographic characteristics shows that respondents can be grouped into their education level based on the answers given to the SN1 indicator.

In relation with the Citarum Harum program, the opinions of people who are considered important to respondents in influencing respondents not to throw garbage into the river at each level of education will be different. The prediction results of grouping the answers of the community in the SN1 indicator at the latest education category can be useful for the implementers of the Citarum Harum program.

The prediction results use to increase the level of participation by placing the right officers as important people to each community with different educational levels to socialize nonsocial movements throw garbage into the river. It can be more powerful if some enviromental policies are formed to make people's enviromental behaviors awareness more strength (Rubimbura et al., 2020).

Enviromental poilicies can be use as catalyst to help Citarum Harum officers to lead the community with different education to participate in Citarum Harum program. Social influences such as enviromental network also important for pro-enviromental behaviors (Ando et al., 2010). 
In other studies, Hadining et al. (2020) shows that theoretical and practical knowledge of the environment influences a person's Attitude To The Behavior, it means that the last level of education will provide different knowledge so that this grouping will have a correlation with community participation in the Citarum Harum program.

Age demographic characteristics have clear differences with the independent variable that gives a difference is the IM2 variable (if I receive an award from a related institution (award, medal, etc.), I will take part in the Citarum Harum program).

These results are correlated with the research results by Hadining et al. (2020) which shows that the incentive measures (IM) factor influences people's behavior intention in the Citarum Harum program and for sure, better incentives can encourage community to do proenviromental behavior (Hu et al., 2018).

This means that by calculating the level of agreement with the community's perceptions in the IM2 indicator with the discriminant function, it can predict which age level the community enters so that it is useful to determine the appropriate award for the community when participating in the Citarum Harum program.

The demographic characteristics of monthly income are distinguished by the independent variables IM2, PN2, and BI1. The three indicators are interrelated with each other, the IM2 questionnaire indicator will have implications because the incentive measures will relate to the monthly income of the respondents, thus helping the Citarum Harum program implementers predict the community's monthly income group.

Likewise with the BI1 variable, by looking at the level of agreement of the respondents in the indicators they will participate in supporting the
Citarum Harum program now and in the future, it can mutually influence the predictions of grouping monthly income along with the PN2 variable.

The benefit that is obtained from grouping monthly income for other Citaum Harum program implementers is that they can mapping the community awareness in the Citarum Harum program by looking at the level of community approval in the indicators IM2, PN2 and BI1. This is in line with research Hadining et al. (2020) which shows that the PN variable influences the behavioral intention of the community in the Citarum Harum program.

\section{Conclusion}

Research on the discriminant analysis of the demographic characteristics of the Cikaobandung village community in the Citarum Harum program found that there were no clear differences in the demographic characteristics group: gender and there were clear differences between groups of demographic characteristics: latest education, monthly income and age.

The independent variable that makes a difference to the age group is the IM2 variable, the independent variable in distinguishing the last education group is the SN1 variable. The independent variables that make a difference to the monthly income group are IM2, PN2 variable and BI1.

\section{Acknowledgement}

Thanks are given to the University of Singaperbangsa Karawang and SATGAS Citarum Harum sectors 14 and 15, Purwakarta, who have provided assistance to finish this research.

\section{References}

Ajzen, I. (2011). The theory of planned behaviour: Reactions and reflections. Psychology and Health, 26(9), 1113-1127. https://doi.org/10.1080/08870446.2011.613 
995

Ando, K., Susumu, O., Anke, B., Ellen, M., \& Junkichi, S. (2010). Determinants of Individual and Collective ProEnvironmental Behaviors: Comparing Germany and Japan. Journal of Enviormental Information Science, 38(5), 21-32.

Azis, A., \& Basuki, I. (2014). Analisa Diskriminan Pada Tingkat Kinerja Pegawai Yang Dipengaruhi Faktor-Faktor Budaya Kerja (Studi Pada Dinas Kebersihan dan Pertamanan Kota Madiun). Epicheirisi, 1, $1-7$.

Badan Pusat Statistik. (2018). Statistik Lingkungan Hidup Indonesia (SLHI) 2018. Badan Pusat Statistik, 1-224. https://doi.org/3305001

Bashiru, S. A., \& Adekunle, K. (2015). An Overview and Application of Discriminant Analysis in Data Analysis. IOSR Journal of Mathematics, 11(1), 12-15. https://doi.org/10.9790/5728-11151215

Baxter, M. . (1994). Stepwise Discriminant Analysis in Archaeometry: a Critique. Journal of Archaeological Science, 21, 659-666.

Chudzinska, M., \& Baralkiewicz, D. (2011). Application of ICP-MS method of determination of 15 elements in honey with chemometric approach for the verification of their authenticity. Food and Chemical Toxicology, 49(11), 2741-2749. https://doi.org/10.1016/j.fct.2011.08.014

Esteban, M., Ferrer, D. M., Vicente, L., Muñoz, A., Claros, F. M., Javier, F., \& Ruiz, O. (2020). University as Change Manager of Attitudes towards Environment (The Importance of Environmental Education). Sustainability, 12.
Etherington, T. R. (2019). Mahalanobis distances and ecological niche modelling: correcting a chi-squared probability error. PeerJ, $1-8$. https://doi.org/10.7717/peerj.6678

Ghorbani, H. (2019). Mahalnobis Distance and its Application for Detecting Multivariate Outliers. Ser. Math. Inform, 34(3), 583595.

Ghozali, I. (2016). Aplikasi Analisis Multivariate Dengan Program IBM SPSS 23 (8 ed.). Badan Penerbit Universitas Diponegoro.

Hadining, A. F., Sari, G. L., \& Sudarjat, H. (2020). Analisis Faktor yang Mempengaruhi Perilaku Masyarakat untuk Berpartisipasi dalam Program Citarum Harum. Al-Ard: Jurnal Teknik Lingkungan, 5(2), 70-79.

Hu, H., Zhang, J., Chu, G., Yang, J., \& Yu, P. (2018). Factors influencing tourists' litter management behavior in mountainous tourism areas in China. Waste Management, 79, 273-286. https://doi.org/10.1016/j.wasman.2018.07. 047

Kamaruddin, S. M., Ahmad, P., \& Alwee, N. (2016). Community Awareness on Environmental Management through Local Agenda 21 (LA21). Procedia - Social and Behavioral Sciences, 222, 729-737. https://doi.org/10.1016/j.sbspro.2016.05.23 4

Kamil, R. (2019). Rencana Aksi Pengendalian Pencemaran dan Kerusakan DAS CItarum. Pemerintah Provinsi Jawa Barat.

Laurens, J. M. (2012). Changing Behavior and Environment in a Community-based Program of the Riverside Community. Procedia - Social and Behavioral Sciences, 36(June 2011), 372-382. https://doi.org/10.1016/j.sbspro.2012.03.04 1 
Li, X., Deng, S., Li, L., \& Jiang, Y. (2019). Outlier Detection Based on Robust Mahalanobis Distance and Its Application. Open Journal Statistic, 9, 15-26. https://doi.org/10.4236/ojs.2019.91002

Louppis, A. P., Karabagias, I. K., \& Papastephanou, C. (2019). Two-Way Characterization of Beekeepers 'Honey According to Botanical Origin on the Basis of Mineral Content Analysis Using ICPOES Implemented with Multiple Chemometric Tools. Foods, 1-13.

Marino, Dewi, Y. S., \& Banyuwnagi, D. P. (2014). Perbandingan Analisis Diskriminan Linier, Diskriminan Linier Robust dan Regresi Logistik Biner. Prosiding Seminar Nasional Matematika, Universitas Jember, November, 192-200.

Prinajati, P. D. (2019). Kualitas Air Waduk Jatiluhur Di Purwakarta Terhadap Pengaruh Keramba Jaring Apung. Journal of Community Based Environmental Engineering and Management, 3(2), 78. https://doi.org/10.23969/jcbeem.v3i2.1838

Rahman, F., \& Sari, D. P. (2018). Penerapan Discriminant Analysis Untuk Mengetahui Faktor Yang Mempengaruhi Tingkat Kepuasan Pengguna Jasa Unit Layanan PPNS. Seminar Master PPNS, 1509, 5154.

Rubimbura, V. M., Idukunda, C., Nsanzabaganwa, J., Yambabariye, E., Nahayo, L., \& Maniragaba, A. (2020). Impact of Community Behavior Change on Environmental Protection in Rwanda. Journal of Environment Protection and Sustainable Development, 6(1), 11-15.

Santos, S., \& Gonçalves, H. M. (2019). Multichannel consumer behaviors in the mobile environment: Using fsQCA and discriminant analysis to understand webrooming motivations. Journal of Business Research, 101(December 2018), 757-766.

https://doi.org/10.1016/j.jbusres.2018.12.0
69

Sari, G. L., Hadining, A. F., \& Sudarjat, H. (2020). Analisis Karakteristik FisikKimiawi Air Daerah Aliran Sungai Citarum Di Waduk Jatiluhur. Jukung (Jurnal Teknik Lingkungan), 6(1), 1-9. https://doi.org/10.20527/jukung.v6i1.8232

Supartini, I. A. M., Sukarsa, I. K. G., \& Srinadi, I. G. A. M. (2017). Analisis Diskriminan Pada Klasifikasi Desa Di Kabupaten Tabanan Menggunakan Metode K-Fold. EJurnal Matematika, 106-115. https://doi.org/10.24843/MTK.2017.v06.i0 2.p154 


\section{Appendix A.}

30 Questionnaire Statement Indicators As Independent Variables

Variable

\section{Indicator Statement}

ATT1 For me, the Citarum Harum program can solve the current waste problem

ATT2 For me, the Citarum Harum program helps accelerate the restoration of water quality in the Citarum River

\begin{tabular}{cl}
\hline ATT3 & For me, throwing garbage in the trash is also part of the Citarum program \\
\hline PBC1 & I have the will to throw it to the right place \\
\hline PBC2 & I have a garbage, so I don't make trash into the river \\
\hline PBC3 & $\begin{array}{l}\text { If I want, I will not throw trash into the river } \\
\text { SN1 }\end{array}$ \\
\hline PN2 & $\begin{array}{l}\text { The people who I consider important, think that I should not throw garbage into the river } \\
\text { Citarum River }\end{array}$ \\
\hline SN3 & $\begin{array}{l}\text { People whose opinions I respect have asked me to invite those closest to me not to throw } \\
\text { garbage into the river }\end{array}$ \\
\hline
\end{tabular}

IM1 If I receive material compensation, I will join the Citarum Harum program.

IM2 If I receive an award from a related institution (honorary charter, medl etc.), I will join the Citarum Harum program.

IM3 If I receive a garbage, I will join the Citarum Harum program.

PN1 Joining the Citarum Harum program makes me feel like a person who is more responsible for protecting the river

PN2 Participating in the Citarum Harum program means that I contribute to protecting the river from being polluted by waste.

PN3 Following the Citarum Harum program, I will make me proud of the behavior that I implement in myself

PB1 I have thrown my trash in the right place in the last two years

PB2 I have been directly involved in river cleaning programs in the last two years

PB3 I have avoided throwing garbage into the river in the last two years

Source: Hadining et al. (2020) 


\section{Appendix A.}

30 Questionnaire Statement Indicators As Independent Variables (Advanced)

Variable

Indicator Statement

ETK1 Preserving the environment is a useful behavior.

Behaviors like getting rid of litter reduce the number of dangerous animals and prevent the

ETK2 spread of disease are environmental behaviors.

ETK3 Disposing of trash in its proper place can help reduce livestock mortality.

EPK1 I know the procedure for disposing of garbage into the place completely.

EPK2 I felt that I understood the Citarum Harum Movement

EPK3 Disposing of trash in the trash can solve the problem of garbage in the river.

GC1 I will not throw garbage into the river when there is a briefing

GC2 I will not throw garbage into the river if there are rules or signs

GC3 I will receive a warning from the village government if I throw garbage into the river.

BI1 I will participate to support the Citarum Harum program from now on and on.

BI2 I try not to pollute the river with waste now and then.

I will be directly involved in the field to realize all efforts to reduce river pollution in the

BI3 framework of the Citarum Harum program now and in the future.

Source: Hadining et al. (2020) 